\title{
Technological Innovation and Competitive Advantage: Empirical Evidence from Large Telecommunication Firms
}

\author{
Perpetua S. Wanaswa ${ }^{1}$, Zachary B. Awino ${ }^{2}$, Martin Ogutu ${ }^{3} \&$ Joseph Owino ${ }^{4}$ \\ ${ }^{1} \mathrm{PhD}$ Candidate, School of Business, University of Nairobi, Kenya \\ ${ }^{2}$ Professor of Strategy-Innovation and Performance Management, School of Business, University of Nairobi, \\ Kenya \\ ${ }^{3}$ Associate Professor, School of Business, University of Nairobi, Kenya \\ ${ }^{4}$ Lecturer, School of Business, University of Nairobi, Kenya \\ Correspondence: Perpetua S. Wanaswa, PhD Candidate, School of Business, University of Nairobi, Kenya. \\ E-mail: sidipw1@gmail.com
}

Received: June 10, 2021

doi:10.5539/ijbm.v16n10p21
Accepted: July 24, 2021

Online Published: August 5, 2021

URL: https://doi.org/10.5539/ijbm.v16n10p21

\begin{abstract}
Empirical research demonstrating the influence of technological innovation on competitive advantage has produced inconclusive results. This paper, therefore, aims to investigate the association amidst technological innovations and competitive advantage. Significant transformations have been evident in Kenya's telecommunication industry for the last two decades, which has resulted in intense competition, and technological innovation has become the new face of competition among firms. The study applied the positivism philosophy and adopted the descriptive cross-sectional survey design. The target population comprised all 83 large licensed telecommunications service providers where census method was used. Both descriptive and inferential statistics were utilized in the analysis of data. Descriptive statistics comprised of frequencies, percentages, means, and standard deviations while inferential statistics used linear regression analysis which was employed in testing the hypothesis. Findings reveal a significant and positive influence of technological innovation on competitive advantage. Technological innovation explained the variations in competitive advantage. It is deduced from the findings that more technologically innovative telecommunication firms are likely to produce better products and services and consequently able to acquire more customers earning competitive advantage compared to less innovative telecommunication firms. The study presented notable implications on the policy framework, the strategic management practice, and theory implications in the telecommunication industry and beyond. At policy level, the Government of Kenya would benefit from the study by ensuring that policy makers and regulatory authorities in the telecommunication sector formulate policies that would promote technological innovation for enhancing competitive advantage. Managerial practitioners may consider institutionalizing innovation by creating the requisite direction and controls that enable the emergence of innovation and value creation for sustainable competitive advantage. The study findings' implications further extended, supported, and added value on the theory adopted by the study.
\end{abstract}

Keywords: Technological innovation, large telecommunication firms, competitive advantage

\section{Introduction}

Researchers and practitioners of strategic management are continuously seeking to establish which factors have the highest impact on competitive advantage. Organizations are competing with one another on the basis of ability to innovate through utilization of knowledge-based resources. Increasingly dynamic and competitive forces of the environment require the ability of business leaders to strategically and proactively manage resources in their control in the form of knowledge assets if they are to achieve desired strategic innovation capability and competitive advantage (Kuusisto \& Meyer, 2015; Miles, 2016). In the contemporary dynamic commercial environment, distinguished by growing globalization, brisk technological alterations and fresher lifestyles, companies which need to stay competitive should be innovative. Technological innovation does not just mean forming new technologies to yield new goods and services, but in most scenarios incorporates looking for new models in order to do business in the changing environment, contemporary, and dynamic world. It 
always involves adjusting the regulations of the game.

This study is anchored on technological networks theory of innovation formulated by Rogers (1983). The theory holds that technological innovation is driven on both internal and external ways. Owing to its overarching description of all the present study variables, the theory is selected as the anchoring theory. In today's global knowledge economy, technological innovation as a process comprises of social interaction as opposed to individual achievement. This implies that innovation integrates both formal and informal associations between firms and organizations on the one hand. On the other hand, innovation involves different actors interacting within networks. Therefore, various intangible forms of capital and social relationships combine to bring about innovation (Karlsson et al., 2013).

Technological innovation stands for the contemporary competitive edge, highly aided by great conventional capabilities in flexibility, efficiency, quality, and speed. Highest performing innovators are capable of maintaining big juggling action of capabilities, and congruously yield latest great quality goods to the economy at a reduced price than competitors, quickly, and more frequently. Furthermore, large telecommunication companies in Kenya employ technological innovation as a method of enhancing their goods and boosting worth to customers. This amalgamation forms a dynamic and sustainable strategic position leading the organization to be a persistent operating earmark to competitors (Gachigo et al., 2019). To gain competitive advantage through technological innovation, the innovation strategy of a company has to be formulated in such a form which encompasses manipulating of the numerous resources through which it exercises direct control in an optimal manner. It is, therefore, important that the innovation strategies adopted by the large information technology firms to earn competitive advantage in such a highly concentrated market yet unbalanced in terms of dominance with one major player controlling at least $70 \%$ of the market are identified.

\section{Literature Review}

Academic interest on the association between innovations that are technologically oriented and competitive positioning continues to grow. Jaskyte (2013), for instance, explored the association between technological association and competitive association and came to the conclusion that the antecedents of technological innovation include activities such as research and development, technique for developing new goods and services, or the advancement of an extant product. The study, however, focused only on the direct link between technological innovation and firms' competitiveness and failed to account for any indirect moderating or mediating factors that may affect the direct association, prompting the present study. This failed to capture the complexities in issues and challenges affecting businesses that would have been effectively solved if the mediating and moderating effect had been considered. In the effort to fill this gap, the current investigation had the mediating as well as moderating elements in the link between technologically resultant innovations and the ability of the firm to remain competitive.

Abdi and Ali (2013) examined the association between technical innovation and business performance in Sub-Sahara Africa with reference to the telecommunication industry in Somalia and found that administrative innovation and technical innovation significantly and positively influence business performance. The study, however, only focused on the financial measures of business performance which only accounted for the quantitative aspects of business performance at the expense of the equally important qualitative aspects. This study employed fundamentally different measures of competitive advantage, accounting for Porters; five forces model of competitive advantage.

Letangule and Letting (2012) explored how the performance of companies in the information technology in Kenya were affected by innovation strategies and found that the adoption of innovation strategies had significant and positive influence on the performance of telecommunication firms. The study, however, focused on the profitability of firms as a measure of organizational performance. Profitability only accounted for the financial measures of performance and did not assess the non-financial measures. To address this, the present study employed a mix of both quantitative and qualitative measures.

In a study to investigate the association amidst companies' innovativeness, strategic directions and performance, Rubera and Kirca, (2012) agreed process innovation results into an organization's paramount outcomes like financial standing and company value. The eventual inclination to observing operational excellence, economies of scale, cost-benefit analysis in raw material procurement, and efficiency are important components to the performance of a company when integrated with strategic innovative processes. The study held that customers would favour goods and services which are produced through adoption of superior technological developments. The study concluded that internally inclined companies follow efficiency as far as all procedures of value chain activities are concerned. These efficiencies include but not limited to low cost or cost leadership strategies hence 
the performance growth of the company.

In a study of the industrial market that focused on association amidst relationship innovation strategy and some attributes of company performance, Jajja et. al., (2017) opined that buyer-seller associations cannot necessarily moderate amidst strategy and performance. This study made a specific observation that in order to obtain technological innovation, companies should reorganize themselves with suppliers that pursue strategic innovations. However, the study only adopted a descriptive study design and used two sample frames, the first in India aiming at 450 companies, and the second in Pakistan aiming at 850 companies.

On researches concerning science, innovation, and technology for competitive advantage Krammer (2017) suggested the need for smart differentiation in advancing economies from which tools and software investment is vital. The study pointed that smart differentiation in advancing economies in Eastern Europe like Bulgaria, and some portions of the world are sustainable if engaged as a block. Such a smart differentiation engagement is best applied to countries which exercise exports of products and services, as this empowers such countries to balance their exports with the expenses involved in buying new tools and software. The disadvantages of regional challenges in buying of tools and software would, hence, be less troublesome, that would yield to greater competitive advantage by information technology firms in the region.

In a study to investigate influence of strategic innovation on performance of telecommunication firms, Kanyuga (2019) investigated the case of Kenya's Safaricom Company. The study concluded that, companies' capability to initiate new improved product to make possible for their entrance and formation of new frontiers for their services, using of contemporary technologies and innovative strategies aimed at specific markets and the bringing about of new good/service patterns affected the companies' performance.

A study by Mugo and Macharia (2020) sought to establish the effect of technological innovation on the competitive edge of telecommunications firms in Kenya. To measure technological innovation, the study used development of Global System of Mobile (GSM) networks, new software and tools, and synergies and partnerships. The results of the research indicated innovation had a significant influence on the competitive edge of information technology firms in Kenya.

\section{Methods}

Primary data was gathered using a semi-structured questionnaire from 83 large licensed telecommunications service providers in Kenya. The study's respondents were Chief Executive Officers (CEOs)/equivalent who understand every aspect of the organization. The research instruments were administered through drop and pick method and in some instances where physical contact was unattainable due to COVID-19, e-mails were used by the researcher assisted by research assistants.

All the 83 large telecommunication firms were approached and served with the questionnaire out of which 61 filled and returned the questionnaires yielding a response rate of $73.5 \%$. According to Awino (2013), a response of above $65 \%$ is acceptable for such studies. The study rate was adequate and compares well to some researches done in the same context. For example Mucai et al. (2018), Mbithi, K'Obonyo and Awino (2016), and Awino (2013).

For this study, technological innovation forming the independent variable was delineated as all innovations in regard to process, product, distribution channel, and information systems. Technological innovation was operationalized along the indicators proposed by Hajir et. al., (2015). Competitive advantage was the dependent variable and was operationalized along the arguments by Porter (1980; 1985), and Afande (2015). Measures of competitive advantage comprised product differentiation and innovation, organizational responsiveness, cost leadership, and supply chain effectiveness.

\section{Results}

Table 1. Model summary for relationship between technological innovation and competitive advantage

Model Summary

\begin{tabular}{llllll} 
Model & $\mathrm{R}$ & R Square & Adjusted R Square & Std. Error of the Estimate & Durbin-Watson \\
\hline 1 & $.349^{\mathrm{a}}$ & .122 & .107 & 2.37356 & 1.599 \\
\hline
\end{tabular}

a. Predictors: (Constant), Technological Innovation.

b. Dependent Variable: Competitive Advantage. 
The findings in Table 1 demonstrate a correlation value $(\mathrm{R})$ of .349 which depicted there was a moderate positive linear association amidst technological innovation and competitive advantage. Goodness of fit $\mathrm{R}^{2}$ value of 0.122 was further established. This indicated that technological innovation explained $12.2 \%$ of the variations in competitive advantage, leaving $87.8 \%$ accounted for by some elements not included in the present regression model. ANOVA test findings were further produced as depicted in Table 2.

Table 2. ANOVA results for relationship between technological innovation and competitive advantage

\begin{tabular}{|c|c|c|c|c|c|c|}
\hline \multicolumn{7}{|c|}{ ANOVA $^{\mathrm{a}}$} \\
\hline & & Sum of Squares & df & Mean Square & $\mathrm{F}$ & Sig. \\
\hline \multirow{3}{*}{1} & Regression & 45.977 & 1 & 45.977 & 8.161 & $.006^{\mathrm{b}}$ \\
\hline & Residual & 332.393 & 59 & 5.634 & & \\
\hline & Total & 378.370 & 60 & & & \\
\hline
\end{tabular}

a. Dependent Variable: Competitive Advantage.

b. Predictors: (Constant), Technological Innovation.

The ANOVA test findings in Table 2 were performed at 95\% confidence level to show the model overall significance. The results $(\mathrm{F}=8.161, \mathrm{p}$-value $=0.006<0.05)$ demonstrated that the model was overall significant, thus could be relied on.

Table 3. Regression coefficients for the association amidst technological innovation and competitive advantage

\begin{tabular}{|c|c|c|c|c|c|c|c|c|}
\hline \multicolumn{9}{|c|}{ Coefficients $^{\mathrm{a}}$} \\
\hline \multirow{2}{*}{\multicolumn{2}{|c|}{ Model }} & \multicolumn{2}{|c|}{ Unstandardized Coefficients } & \multirow{2}{*}{$\begin{array}{l}\text { Standardized Coefficients } \\
\text { Beta }\end{array}$} & \multirow{2}{*}{$\mathrm{t}$} & \multirow{2}{*}{ Sig. } & \multicolumn{2}{|c|}{ Collinearity Statistics } \\
\hline & & $\mathrm{B}$ & Std. Error & & & & Tolerance & VIF \\
\hline \multirow{2}{*}{1} & (Constant) & 9.599 & 2.990 & & 3.210 & .002 & & \\
\hline & Technological Innovation & .438 & .153 & .349 & 2.857 & .006 & 1.000 & 1.000 \\
\hline
\end{tabular}

a. Dependent Variable: Competitive Advantage.

The results in Table 3 revealed that technological innovation had significant positive influence on competitive advantage $(\beta=.349, \mathrm{t}=2.857, \mathrm{p} \leq 0.05)$. Therefore, the hypothesis that technological innovation has a significant influence on competitive edge was supported. Table 4 depicts a synopsis of the test results for the hypothesis.

Table 4. Summary test results for hypothesis

\begin{tabular}{|c|c|c|c|c|c|}
\hline Hypothesis & Beta & $\mathbf{R}$ & $\mathbf{R}^{2}$ & Sig. & Conclusion \\
\hline $\begin{array}{l}\mathrm{H}: \text { Technological innovation has a significant influence on } \\
\text { competitive advantage }\end{array}$ & .349 & .349 & .122 & $\begin{array}{c}\mathrm{p}=.006 \\
<.05\end{array}$ & $\begin{array}{l}\text { Hypothesis } \\
\text { supported }\end{array}$ \\
\hline
\end{tabular}

The summary outcomes in Table 4 revealed technological innovation had a statistically significant influence on competitive advantage as indicated by a statistically significant standard beta value of .349 and p-value $(0.006<0.05)$. Goodness of fit elucidated that technological innovation explained $12.2 \%$ of the variance in competitive advantage. The regression model can thus be written as follows:

$\mathrm{CA}=9.599+.349 \mathrm{TI}$

Where:

$\mathrm{CA}=$ Competitive Advantage

$\mathrm{TI}=$ Technological Innovation

The standardized beta coefficient of 0.349 implies that for every $1 \%$ change in technological innovation, there was a corresponding $0.349 \%$ change in competitive advantage, holding other factors constant.

\section{Conclusion}

The objective for the research was to establish the effect of technological innovation on competitive advantage. 
This corresponded with the hypothesis stated as $H$ : Technological innovation has a significant effect on the competitive advantage. To realize this objective and correspondingly test the stated hypothesis, the independent variable, technological innovation was measured by five sub-constructs, that is, process innovation, product innovation, information system innovations, operation system innovation, and distribution channel innovations while the dependent variable, competitive advantage was measured by four sub-constructs, including cost leadership, organizational responsiveness, product differentiation and innovation and supply chain effectiveness.

The study proceeded to examine the hypothesis employing a simple linear regression model. Research outcomes revealed that technological innovation had significant positive influence on competitive advantage $(\beta=.349, \mathrm{t}=$ $2.857, \mathrm{p} \leq 0.05$ ). This implied that for every $1 \%$ change in technological innovation, there was a corresponding $0.349 \%$ change in competitive advantage across the telecommunication firms surveyed.

The study, therefore, supported the hypothesis, illustrating technological innovation as having a significant influence on competitive advantage. The foregoing finding can be attributed to the telecommunication industry being technologically intensive, driven primarily by technological innovations. As such, firms with the greatest number of technological innovations are deemed more innovative and have a higher chance of outcompeting firms with less technological innovations which are deemed less innovative. Moreover, technologically innovative telecommunication firms are likely to produce better products and services and consequently able to attract more users and eventually command a larger market share as compared to less innovative telecommunication firms.

The study finding is in tandem with Abdi and Ali (2013) who examined the association between technical innovation and business performance in Sub-Sahara Africa with reference to the telecommunication industry in Somalia and found that administrative innovation and technical innovation significantly and positively influenced business performance. The finding is also consistent with Letangule and Letting (2012) who explored how the performance of companies in the information technology firms in Kenya are affected by innovation strategies and established the adoption of innovation strategies had a positive and significant influence on the performance of telecommunication firms.

The research outcome was further in agreement with Distanont and Khongmalai (2018) in whose study on the responsibility of innovation in forming a competitive advantage in Thailand found that innovation had a significant positive influence on competitive edge. Accordingly, technological innovation had been widely reported in literature to be a paramount element in several facets of business competition. Goksoy, Vayvay and Ergeneli (2013) report in their study that technological innovation enables firms to present improved or new services or products into the market before their rivals and, therefore, resulting in the market share growth.

Lim, Chesbrough and Ruan (2010) postulated that numerous firms thrive and had been triumphant due to technological innovation, which builds competitive advantage for them, as it enables the firm build long-term competition by collecting skills in technology, knowledge, and experience in development and creativity and initiating new ideals in the type of business model, process, or product innovations. According to Porter (1998), the competitive advantages can arise from services and goods display exceptional dissimilarities from the characteristic goods or services in the respective sector.

Research outcomes are in tandem with Kanyuga (2019) who investigated the case of Kenya's Safaricom Company. The study concluded that, companies' capability to initiate new improved product to make possible for their entrance and formation of new frontiers for their services, using of contemporary technologies and innovative strategies aimed at specific markets and the bringing about of new good/service patterns affected the companies' performance.

The findings of the study are in congruent with Adede, Kibera and Owino (2017) following their study to find out the influence of e-marketing exercises on the performance of information technology firms in Kenya using competitive environment as a mediating variable. They observed that the need for firms to answer to adjustments within the competitive surrounding had yielded to high attention to the way organization's resources are used to affect performance. Competitive surrounding plays an important responsibility in the mapping out of organizational victory or failure as a result of the volatility and complexity in the surrounding. Firms capable of adapting to the disputes arising in the competitive surrounding often form winning strategies (these could include technological innovations) that help the firms report stellar performance.

On the contradictory, when firms do not check and answer to competitive surroundings accordingly, competition has the capability to undermine the power of the formulated marketing strategies. Competition, therefore, affects firms differently and this depends mainly on the industry structure and conditions of the market. The study informed policy makers and strategic leaders in Kenya's large telecommunication firms that development of 
mechanisms that enable adaptation to the dynamisms in the competitive environment with appropriate strategies contribute to better organizational performance. The findings of the study are also in agreement with study by Mugo and Macharia (2020) that investigated the effect of technological innovation on the competitive advantage of telecommunications companies in Kenya and established that technological innovation had a significant effect on the competitive edge of information technology firms in Kenya.

The finding further offers support to the dynamic capabilities' theory postulated by Teece et al. (1997) which holds that if the unique resources owned by an organization are well utilized, they can lead to a competitive position. In line with the theory, technological innovativeness of telecommunication firms can be perceived as dynamic capabilities which innovative firms leverage and constantly reconfigure in tandem with the dynamic user demands and advancements in technology. Accordingly, Teece et al. (1997) intimated that in order for enterprises to create responsive capabilities and stay competitive, intangible firm resources like skills, knowledge, and innovativeness ought to be constantly adapted and reconfigured to the ever-turbulent environmental forces.

The primary objective of the study was to determine the effect of technological innovation on competitive advantage. It is concluded based on the research outcomes that the hypothesis underpinning the research is substantiated as per the technological network's theory of innovation as well as Porter's sustainable competitive advantage model. The study particularly concludes that change in technological innovation would lead to a major change in competitive advantage. This could be attributed to the telecommunication industry being technologically intensive, driven primarily by technological innovations. As such, firms with the most number of technological innovations are deemed more innovative and have a higher chance of outcompeting firms with less technological innovations which are deemed less innovative. More technologically innovative telecommunication firms are likely to produce better products and services and consequently able to attract more users and eventually command a larger market share as compared to less innovative telecommunication firms.

Additionally, from the research outcomes it can be concluded that technological innovation in the information technology sector were implemented for enhancement of competitive advantage. This was evident from the way respondents answered questions and the analysis arising thereof. This research ascertained that for a firm to have a competitive advantage, technological innovation was most important. It could, therefore, be concluded that this could assist in monitoring both the internal and external environments to establish the technological innovation to be implemented.

\section{Implications of the Study}

The study has uncovered that competitive advantage among firms in the telecommunication industry was affected by technological innovation. As such, in light of this finding, it is recommended that the policy makers and regulatory authorities in the Government of Kenya, particularly in the telecommunication sector formulate policies that would promote technological innovation as a strategy for competitive advantage enhancement among firms in the industry. This also protects the end-product consumers from such unfair practices as brought about by monopoly.

The study has established technological innovations positively and significantly influence competitive advantage among telecommunication firms in Kenya. Considering that the life span of technologies, technological products, and processes are rapidly shortening, firms in such a technology-driven industry as telecommunication are urged to develop innovative cultures that enable and encourage constantly finding and creating new technological innovations. The study particularly recommends that firms adopt flexibility to respond to any environmental change that warrants new and differentiated products and services so as to not only sustain their existence, but also achieve sustainable competitive advantage.

The findings of the research further extend the arguments of technological networks theory of innovation which was proposed by Rogers (1983) and opines that technological innovation is primarily driven in both internal and external means. Further, the study findings were found to be consistent with Porter's model of sustainable competitive advantage (Porter, 1985). Telecommunication firms were found to leverage both product differentiation and innovation as well as cost leadership to earn a competitive advantage and acquire more customers. 


\section{Acknowledgements}

I respectfully acknowledge my co-authors: Prof. Zachary B. Awino, Prof. Martin Ogutu, and Dr. Joseph O. Owino for their dedication, guidance, and intellectual contributions which were immeasurable. I sincerely thank you for your contributions and hold you in the highest esteem ever.

\section{References}

Abdi, A. M. \& Ali, A. Y. (2013). Innovation and business performance in telecommunication industry in Sub-Saharan African context: Case of Somalia. Asian Journal of Management Sciences and Education, 2(4), 53-67.

Adede. A. O., Kibera, F. N., \& Owino, J. O. (2017). Electronic marketing practices, competitive environment and performance of telecommunications companies in Kenya. British Journal of Marketing Studies, 5(5), 60-67.

Afande, F. O. (2015). Competitive strategies and firm performance in the mobile telecommunication service industry: a case of Safaricom Kenya limited. Developing Country Studies, 5(3), 15-34.

Awino, Z. B. (2013). Strategic planning and competitive advantage of ICT small and medium enterprises in Kenya. Business and Management Horizons, 1(1), 191-204.

Chege, S. M., Wang, D., \& Suntu, S. L. (2020). Impact of information technology innovation on firm performance in Kenya. Information Technology for Development, 26(2), 316-345. https://doi.org/10.1080/02681102.2019.1573717

Communications Authority of Kenya. (2020). Fourth quarter sector statistics report for the financial year 2019/2020.

from https://ca.go.ke/wp-content/uploads/2020/07/Sector-Statistics-Report-Q3-2019-2020-.pdf

Drucker, P. (2018). Innovation and Entrepreneurship. Routledge.

Drucker, P. F. (1985). Innovation and entrepreneurship. Oxford, UK, Butterworth-Heinemann, Ltd.

Gachigo, S. M., Kahuthia, J., \& Muraguri, C. (2019). Exploration innovative strategy and performance of the telecommunication industry in Kenya: a case of Safaricom Plc in Nairobi Metropolis. International Academic Journal of Human Resource and Business Administration, 3(6), 299-319.

Goksoy, A., Vayvay, O., \& Ergeneli, N. (2013). Gaining competitive advantage through innovation strategies: an application in warehouse management processes. American Journal of Business and Management, 2(4), 304-321. https://doi.org/10.11634/216796061706463

Government of Kenya. (2007). Kenya vision 2030: a globally competitive and prosperous Kenya. Government printers, Nairobi, Kenya.

Hajjir, J. A., Al-dalanhmeh, M., Masa'deh, R., \& Obeidat, B. (2015). The role of knowledge management infrastructure in enhancing innovation at mobile telecommunication companies in Jordan. European Journal of Social Sciences, 50(3), 313-330.

Institute of Economic Affairs. (2018). The telkom sector in Kenya: a historical journey from 1999 to date. Nairobi, Kenya.

Jajja, M. S., Kannan, V. R., Brah, S. A., \& Hassan, S. Z. (2017). Linkages between firm innovation strategy, suppliers, product innovation, and business performance. International Journal of Operations and Production Management, 37(8), 1054-1075. https://doi.org/10.1108/IJOPM-09-2014-0424

Jaskyte, K. (2011). Predictors of administrative and technological innovations in nonprofit organizations. Public Administration Review, 71(1), 77-86. https://doi.org/10.1111/j.1540-6210.2010.02308.x

Kanyuga, L. (2019). Influence of strategic innovation on performance of telecommunication firms: a case of Safaricom Company. Journal of Strategic Management, 3(1), 21-39.

Karlsson, C., Johansson, B., \& Stough, R. (2013). Innovation, technology and knowledge. New York, Routledge.

Krammer, S. M. (2017). Science, technology, and innovation for economic competitiveness: the role of smart specialization in less-developed countries. Technological Forecasting and Social Change, 123, 95-107. https://doi.org/10.1016/j.techfore.2017.06.028

Kuusisto, J. \& Meyer, M. (2015). Insights into services and innovation in the knowledge-intensive economy, Technology Review 134/2003. Tekes National Technology Agency, Helsinki. 
Letangule, S. L., \& Letting, N. K. (2012). Effect of innovation strategies on performance of firms in the telecommunication sector in Kenya. International Journal of Management \& Business Studies, 2(3), 75-78.

Lewis, M. A. (2016). Lean production and sustainable competitive advantage. International Journal of Operations \& Production Management, 20(8), 959-978. https://doi.org/10.1108/01443570010332971

Lim, K., Chesbrough, H., \& Ruan, Y. (2010). Open innovation and patterns of research and development competition. International Journal of Technology Management, 52(3/4), 295-321. https://doi.org/10.1504/IJTM.2010.035978

Mathenge, J. (2013). The effect of innovation on competitive advantage of telecommunication companies in Kenya (Unpublished Dissertation), University of Nairobi, Kenya. Retrieved from https://pdfs.semanticscholar.org/df12/3831d6336c6305714ead059d266819edf913.pdf

Mugo, P., \& Macharia, J. (2020). Technological innovation and competitive advantage in telecommunications companies. International Journal of Research in Business \& Social Science, 9(5), 38-47. https://doi.org/10.20525/ijrbs.v9i5.866

Mukhtar, U. (2015). Supply chain competitiveness with the perspective of service performance between supply chain actors: a theoretical model. Technology, Innovation \& Industrial Management.

Oughton, E., Frias, Z, Russell, T, Sicker, D., \& Cleevely, D. D. (2018). Towards 5G: scenario-based assessment of the future supply and demand for mobile telecommunications infrastructure. Technological Forecasting \& Social Change, 133, 141-155. https://doi.org/10.1016/j.techfore.2018.03.016

Porter, M. E. (1980). Competitive strategy (pp. 34-41). New York, Free Press.

Porter, M. E. (1985). Competitive strategy. New York, Free Press.

Porter, M. E. (1990). The competitive advantage of nations. Harvard Business Review. Retrieved from https://hbr.org/1990/03/the-competitive-advantage-of-nations

Porter, M. E. (1998). Competitive strategy: techniques for analyzing industries and competitors. New York, NY, Free Press.

Porter, M. E. (1998). What is strategy? Harvard Business Review, 74(6), 61-78.

Rajapathirana, R. J. \& Hui, Y. (2018). Relationship between innovation capability, innovation type, and firm performance. Journal of Innovation and Knowledge, 3(1), 44-55. https://doi.org/10.1016/j.jik.2017.06.002

Ritala, P., \& Ellonen, H. K. (2019). Competitive advantage in inter firm cooperation: old and new explanations. Competitiveness review, An International Business Journal, 20(5), 367-383. https://doi.org/10.1177/0149206320901565

Rogers, E. M. (1983). Diffusion of innovations (4th ed.). New York: The Free Press.

Rubera, G., \& Kirca, A. H. (2012). Firm innovativeness and its performance outcomes: a meta- analytic review and theoretical integration. Journal of Marketing, 76(3), 130-147. https://doi.org/10.1509/jm.10.0494

Sigalas, C., Economou, V. P., \& Georgopoulos, N. B. (2018). Developing a measure of competitive advantage. Journal of Strategy and Management, 6(4), 320-342.

Teece, J. D., Pisano, G., \& Shuen, A. (1997). Dynamic capabilities and strategic management. Strategic Management Journal, 18(7), 509-533. https://doi.org/10.1017/jmo.2017.75

Un, C. A., \& Asakawa, K. (2015). Types of research and development collaborations and process innovation: the benefit of collaborating upstream in the knowledge chain. The Journal of Product Innovation Management, 32(1), 138-153. https://doi.org/10.1111/jpim.12229

World Economic Outlook (WEO) Report. (2019). Retrieved from https://www.imf.org/en/Publications/WEO/Issues/2019/07/18/WEOupdateJuly2019

\section{Copyrights}

Copyright for this article is retained by the author(s), with first publication rights granted to the journal.

This is an open-access article distributed under the terms and conditions of the Creative Commons Attribution license (http://creativecommons.org/licenses/by/4.0/). 